Protection to appoint a receiver. Relatives are therefore encouraged to have a donor sign an EPA during 'a period of lucidity'. It is my experience that those who are psychiatrically untrained have difficulties with this-often believing, for example, that someone who is talking clearly about the past is having a 'lucid' period, while they may have no knowledge of their current business affairs;

(3) abuse of the EPA by the appointee for their own gain.

In my view we should be lobbying for a change in the law to ensure that a medical opinion is compulsory prior to the signing of a EPA. With this in mind, I would be pleased to hear from those experiencing the same concerns.

Psychogeriatric Department,

LINDA A. HARDWICK

St James' Hospital,

Locksway Road,

Portsmouth

\section{Child victims of domestic cruelty}

DeAr Sirs

The letter by Dr J. E. Oliver (Bulletin, April 1988) deserves support, not only for its cogent analysis of the mistakes made in the handling of child abuse by professionals and social agencies, but also because his views are based on realistic clinical work with highly disturbed families. Dr Oliver's letter highlights two flawed principles, overtly or covertly, influencing professional workers.

The first principle maintains that in all circumstances a child's own home is better than any other home; i.e. that separation of a child from its mother leads to calamitous consequences for a child's emotional health. Thus Maria Colwell ${ }^{1}$ and Jasmine Beckford ${ }^{2}$ were returned to the care of their parents and killed by them. This principle is flawed in that it confuses the situation of separation with the process of deprivation ${ }^{3}$. Non separation, that is being with a destructive parent, can lead to damaged emotional health and sometimes death; the damage is due to the process of deprivation in a situation of non separation. It follows that separation leading to non deprivatory care in a happy foster home can promote emotional health and save life.

The second principle maintains that children are not citizens in their own right, but are chattels of the parents, as wives were chattels of their husbands not very long ago. The answer is seen in the Godfrey report" which said "Men and women now stand more or less equal before the law" and went on to recommend "In all proceedings relating to the welfare of a child the law should provide that the child be made a party to the proceedings and be entitled to separate and equal representation ...". This is in accord with Foster \& Freed's "A Bill of Rights for Children"s and the United Nations General Assembly's "Declaration on the Rights of the Child". Thus men, women and children will stand equal before the law.

J. G. Howells

Higham St Mary

Colchester

\section{References}

${ }^{1}$ Report of the Committee of Inquiry into the Care and Supervision Provided in Relation to Maria Colwell (1974).

${ }^{2}$ A Child in Trust: The Report of the Panel of Inquiry into the circumstances surrounding the death of Jasmine Beckford (1985). London: Borough of Brent.

${ }^{3}$ Howells, J. G. (1974) Remember Maria. London: Butterworths.

${ }^{4}$ Parental Rights and Duties and Custody Suits. A Report by JUSTICE. Chairman: G. Godfrey (1975). London: Stevens.

${ }^{5}$ Foster, H. \& FreEd, D. (1972) A Bill of Rights for Children. Family Law Quarterly, VI, 345.

\section{Psychiatry in South Africa}

\section{DeAR SIRS}

I write in the context of Dr R. E. Hemphill's letter from South Africa (Bulletin, April 1988). I was present at the quarterly business meeting of 28 January 1987 when a resolution for sanctions against South Africa was passed. It is unfortunate that the Chairman did not count abstentions and these were not recorded or later publicised. There was at least one, myself.

Having worked as a psychiatrist in both New Zealand and Australia, I knew at first hand of the respect invested in the College by members and other colleagues overseas and surmised that its influence in South Africa would be equivalent, probably greater. I visited South Africa for five weeks during 1982 on holiday, but had the opportunity to visit academic departments of psychiatry in Johannesburg and Durban, visiting several hospitals and meeting two professors. I took careful note of what they had to tell me about medicine and psychiatry in South Africa, recent changes, prospects for the future and so on. I realised that a most powerful and commendable humanitarian spirit could be found there struggling against the political odds.

When the resolution was put to the 28 January meeting, like Dr Hemphill, I found myself seriously doubting whether it was appropriate for the College to be discussing these essentially political matters at all. We are each free to make whatever protestations 